\title{
Response to Mark Fettes' Review of The New Significance of Learning: Imagination's Heartwork
}

\author{
Pádraig Hogan
}

Published online: 24 February 2011

(C) Springer Science+Business Media B.V. 2011

I'm grateful to Mark Fettes for taking the time to review my book in an essay length piece. Yet I'm quite surprised to discover that the review largely bypasses the book's central theme. That theme is an exploration of the claim that education is a practice in its own right. Far from being a 'familiar complaint', this claim is a rarely-made one, even by today's more forceful critics of bureaucratic control of education. Far from being the plea of a well-meaning moderate moreover, it is a radical idea on any historical appraisal; as unwelcome to many of today's Western governments as were the claims of previous times for extending the electoral franchise to non-land holders, religious dissenters, women, or diverse ethnic groups. For these reasons the historical-philosophical account of the colonisation of education in the book's Introduction and opening chapter is crucial. It sets the context for all that follows. Without that context, which Dr. Fettes doesn't refer to, the book's arguments on behalf of education as a practice with its own integrity may look counter-intuitive, even bit odd. In his opening paragraph Dr. Fettes equates my attempts to define and justify the integrity of education as a practice with the efforts of educators to become 'adept at defending their own interests.' This is so wide of the mark that the review gets onto a peculiar path from the start. I welcome this opportunity therefore to try to set matters to rights.

In Western civilisations the historic effects of a Platonist aspiration, together with many centuries of church control of education, have propagated the idea that education is essentially a subordinate undertaking, as distinct from a practice in its own right. In other words, it seems quite natural to believe that education as a public practice must take its character and tenor from a class of superiors. Ascendant secular authorities during the 19th century aftermath of the Enlightenment retained the idea that education was a subordinate undertaking; a machinery available to the powers-that-be that would carry the stamp of these powers. Despite some recurring turbulence, this largely continued to be the case throughout the twentieth century. But the idea was newly invigorated by the international educational reforms of the last quarter century. Where each general election can fundamentally recast the educational order of things, this reveals the extent to which education

P. Hogan $(\bowtie)$

Education Department, National University of Ireland Maynooth, Maynooth, Co., Kildare, Ireland e-mail: Padraig.Hogan@nuim.ie 
as a practice remains colonised. It is against this larger historical and more recent backdrop that my own enquiries take place.

Dr. Fettes sees 'a clear moral heart to Hogan's project', but argues that the edge to my enquiry is blunted by a desire to accommodate the case I'm making 'within existing social structures and cultural practices.' On this reading, my argument is too 'consensualist', too 'moderate and reasonable'. Admittedly, there are enticements in engaging in the more combative kind of discourse that Dr. Fettes seems to prefer. But if one's concern is to elucidate the coherence of a beleaguered practice, and to advance that coherence by unequivocally democratic means, the chief emphasis must remain on searching exploration, and on the giving of warranted reasons. A key part of that exploration for me has been the recovery and probing of overlooked insights that are discernible in the practices of Socrates, as recounted in the early (not the middle or later) dialogues of Plato. Similarly central to my explorations are insights from the writings of Gadamer, which on first acquaintance I resisted as relativistic, but which I later had to acknowledge as unavoidable, indeed educationally fruitful. In my explorations there are, clearly, some disagreements with thinkers like Foucault, Lyotard, Derrida and, in a more specific way, with MacIntyre. This isn't 'sparring' of any kind, however. I acknowledge the revelatory power of the critical insights contributed by the former three. I also comment on suggestive departures in the later work of Foucault (truth-telling/parrhesia) and Derrida (a 'justice yet to come') that might be significant for education as a coherent practice. Where enhancing and advancing such practice are concerned, however, the effects of postmodern currents of thinking have been mainly debilitating. This has unfortunately left the public arena more susceptible to the rise of newly colonising conceptions of education, not least through the educational reforms of recent decades. My disagreement with MacIntyre is more specific, and indeed more serious, though I am also clearly indebted to his work for its perceptive elucidation of the notion of practice. I would have welcomed some comments in Dr. Fettes' review on my own engagement with MacIntyre, which is a central feature of the book.

Dr. Fettes remarks that I am too silent on where my 'philosophy is grounded'. I'd have thought the many illustrations from experience in the book have said plenty on this. However, breaking that silence here with some salient points from my own philosophical journey may be the best way to respond to Dr. Fettes' criticisms, and to highlight the kind of path the book seeks to mark out. The account of human understanding contained in the book is one that acknowledges my deeper debt to writers like Gadamer and Heidegger. Dr. Fettes suggests that I have 'opted for' Gadamer's notion of cultural tradition as a kind of conversational partner, to the neglect of a more radical attentiveness to different traditions. In fact it was never a question as simple as opting for this rather than that. Unsettling my earlier attachments to a rationalist epistemology, the writings of Heidegger and Gadamer eventually convinced me in my mid-twenties of something my own experience as a struggling teacher had been continually putting under my nose: that human understanding itself has inherent limitations which the best exercise of reason can't overcome; that even the most accomplished human understanding is inescapably partial, and in both senses of the word-incomplete and biased. If 'biased' sounds too strong here, then let me say 'predisposed by prior influences', some of which may be in unacknowledged conflict with each other. It is the totality of such influences, from the remote past to the most recent, that constitutes 'tradition' in Gadamer's sense of the word. This is quite distinct from the conception of tradition as a specific body of beliefs and commitmentsCatholic, Marxist, utilitarian, and so on. To conceive of tradition as partly-hidden totalities of influence (Überlieferung), encountered by culturally-situated experience, is of seminal importance for practices of teaching and learning. It is far from the 'conservative' leanings 
many mistakenly attribute to Gadamer, or from what Dr. Fettes designates 'the standard hermeneutic account.'

As these previously foreign ideas began to pervade my thoughts and actions it dawned on me that the betterment of understanding, and particularly through practices of education, requires the cultivation of a certain disposition, or discipline. That discipline, particularly fertile for educational practitioners, is one of critical pedagogical dialogue: of being disposed to listen to and engage with the perspectives of others, in all their plurality (not least Vygotskian and Aboriginal perspectives). Its practical purposes are those of enabling educational experience to venture with progressive fluency into inclusive landscapes of learning that offer genuine possibility and hope. It is the embrace, not the avoidance, of the far-reaching implications of this that suggested the title The New Significance of Learning.

Returning to the early dialogues of Plato in my early 30s-Gorgias, Protagoras, Euthyphro, Republic Bk1 - provided a shock, indeed a revelation. For here, in the quality of engagement and in the inconclusive but suggestive endings of the encounters, lay Socrates' implicit recognition of the two features (incompleteness and pre-judgement) that I had been fully crediting to twentieth-century philosophical researches. True, the Athenian learning environments were far less heterogeneous than these of today's educational settings. But their exclusionary aspects did not obscure from me their more promising features. It struck me forcefully that these promising features merited further investigation. They seemed quite at odds with the paternalistic conceptions of education canvassed in Plato's later works, especially works like Republic Bk II-X and Laws. Historical researches then disclosed to me how thoroughly some custodial ideas of the later Plato were subsequently championed, in one version or another, by the Neo-Platonist cast of European Christendom. The less conspicuous corollary of this is how thoroughly the earlier Socratic example was eclipsed. Apart from an occasional budding, it never became anything like an established tradition, in the usual sense of the word. To use MacIntyre's language, it never became an institutionally supported practice.

Dr. Fettes is right to say that my view of education is culturally specific one. To some degree or other that's the case with everything that is a human practice. That doesn't alter the point that education as a practice, or more precisely a recognisable family of practices, must endeavour to remain a worthy candidate for justification on universal grounds; worthy of the commitments of practitioners who recognise its capacity for cultivating the hopes of humanity ever anew, even amid partisan legacies that have more than occasionally been of its own making. 